International Journal of Linguistics, Literature and Translation

ISSN: 2617-0299 (Online); ISSN: 2708-0099 (Print)

DOI: $10.32996 / \mathrm{ijllt}$

Journal Homepage: www.al-kindipublisher.com/index.php/ijltt

IJLLT

\title{
Impoliteness Manoeuvres and Its Motives in Indonesia Lawyers Club Talk Show
}

\author{
Dita Sukmawati Putri ${ }^{1} \square$ Djatmika $^{2}$ and Miftah Nugroho ${ }^{3}$ \\ 1'Postgraduate Student, Linguistic Program, Sebelas Maret University, Surakarta Indonesia \\ ${ }^{2}$ Professor, Linguistic Program, Sebelas Maret University, Surakarta, Indonesia \\ ${ }^{3}$ Lecturer, Linguistic Program, Sebelas Maret University, Surakarta, Indonesia \\ $\square$ Corresponding Author: Dita Sukmawati Putri, E-mail: ditasukma@ymail.com
}

\section{ARTICLE INFORMATION ABSTRACT}

Received: 10 October 2021

Accepted: 15 November 2021

Published: 21 December 2021

DOI: $10.32996 /$ ijllt.2021.4.12.14

\section{KEYWORDS}

Impoliteness, Indonesia Lawyers

Club, ILC, talkshow, face-

threatening
The use of impolite language is often found in various areas of conversation, both formal and informal conversations. Being polite is different from speaking rudely. Impoliteness is often expressed with harsh words. Impoliteness can be expressed even with a sentence of praise. The Indonesia Lawyers Club talk show is a television program that presents formal discussions on political and government issues in Indonesia. This study focuses on the reasons for using impoliteness that occurs in the dialogue on the Indonesia Lawyers Club talk show. This research is a qualitative descriptive study using a pragmatic approach. The data in this study are in the form of dialogues that contain impoliteness. The source of this research data is taken from the talk show Indonesia Lawyers Club. The data analyzed in this study are in the form of natural oral data. The data analysis method used is the referential equivalent method. The presentation of data analysis used is informal presentation techniques. The results of this study indicate the discovery of 4 impoliteness strategies and 3 reasons for using impoliteness. The 4 strategies are bald on record, positive impoliteness, negative impoliteness, and mock politeness. The reasons for using impoliteness in the Indonesia Lawyers Club talk show include the feeling that their opinion is the most correct, wanting to embarrass the speech partner and the speaker's personal interests.

\section{Introduction}

The use of impolite language is now increasingly found in various conversation areas, both formal and informal conversations. Being polite is different from speaking rudely. Speaking disrespectfully is not always expressed with harsh words. Disrespectful speech or impoliteness can be expressed even with a sentence of praise. Therefore, a pragmatic approach needs to be used in researching impoliteness. Bousfield (2008: 3) defines "Impoliteness as behaviour that is face-aggravating in a particular context. The face-threatening behaviour referred to here is an utterance that can embarrass the interlocutor. Goffman first put forward the concept of the face (1967), face the public self-image that every member wants to claim. Goffman (1967) divides the face into two, namely positive face and negative face. A positive face is a person's desire to be accepted, treated equally, and appreciated for his beliefs. In contrast, the negative face is the individual's desire to be independent, to have freedom of activity, including opinion, without being restrained or coerced from anywhere.

The impoliteness that will be discussed in this study is impoliteness in language, where language is used as a tool to attack the interlocutor's face. Impoliteness, according to Culpeper (2005a: 38), "comes about when: (1) the speaker communicates face-attack intentionally, or (2) the hearer perceives and/or constructs behaviour as intentionally face-attacking, or a combination of (1) and (2)". Language of impoliteness always considers the context and speech situation. Based on definitions from various experts, in general, impoliteness can be defined as a language activity that is intentionally intended to damage interpersonal relationships or attack the face of a speech partner (Archer, 2008; Bousfield, 2008; Culpeper, 1996; Limberg, 2009).

Based on the searches that have been carried out, currently, many studies discuss the use of language intending to damage or attack the speech partner's face, both in everyday life and in television shows. Many television programs are found to no longer

Copyright: (c) 2021 the Author(s). This article is an open access article distributed under the terms and conditions of the Creative Commons Attribution (CC-BY) 4.0 license (https://creativecommons.org/licenses/by/4.0/). Published by Al-Kindi Centre for Research and Development, London, United Kingdom. 
heed politeness in speech. The forms of speech strategies that contain impoliteness also take various forms. This is certainly an interesting linguistic phenomenon to be re-examined. Of the many television shows, one that often shows impoliteness activities is the Indonesia Lawyer Club talk show.

Reporting from the Wikipedia page, the Indonesian Lawyers Club or hereinafter referred to as the abbreviation ILC is a talk show broadcast live by the national television station, TVOne. The ILC event featured in-depth discussions on issues currently being discussed in Indonesia. Not only that, but ILC also presented several expert speakers on each topic discussed. The program, hosted by Karni llyas, airs every Tuesday at 20.00 WIB and Sunday at 19.30 WIB. with a duration of 210 minutes. As a television program that has been nominated for nine years in a row as the best talk show program, ILC has also received a warning from the Indonesian Broadcasting Commission (KPI), resulting in the absence of the event in early 2017. As the best talk show program, ILC has presented hundreds of speakers from various fields, such as law, politics, religion, health, environment etc. Thus, through the ILC and knowledge from resource persons and the latest issues, the use of language is also interesting to note.

Every speech must have a purpose. Some aim to strengthen the relationship between speakers, while others aim to stretch or damage the relationship between speakers. Impoliteness is an interaction that is intentionally used to damage the relationship between speakers. In addition to the purpose of damaging the face of the interlocutor, impoliteness certainly does not just arise, but some factors influence the occurrence of impoliteness. Culpeper (1996) describes the factors of using impoliteness, including the social relations of the speaker, differences in social level, and deliberately not wanting to keep the face of the interlocutor. Based on these three factors, the formulation of the reasons for using impoliteness in the ILC talk show will refer to the third factor, namely the speaker's desire, who deliberately does not want to keep the interlocutor's face. The first and second factors, namely the difference in social level between speakers and social closeness between speakers, are considered equally owned by speakers and speech partners in ILC talk shows. Speakers in ILC talk shows have the same social closeness between speakers with one another, namely social relations that are not too close/familiar. Likewise, with the social level of the speakers, in the talk show ILC, the speakers, on average, have the same social level; therefore, they are used as resource persons in the talk show.

The third factor, namely the desire of the speaker who deliberately does not want to keep the interlocutor's face, was chosen because it is the most relevant factor to find the background of the use of impoliteness in the ILC talk show. Therefore, this study will explain the reason for the occurrence of impoliteness when the speaker and the speech partner have the same level of social closeness and the same social level. What is the speaker's desire who deliberately does not want to keep the face of the interlocutor? This study will describe the reasons behind the speaker who does not want to keep the face of the speech partner is.

\subsection{Research Objectives:}

Based on the background described, the purpose of this study is to find out the forms of impoliteness and the reasons for using impoliteness on the talk show Indonesia Lawyers Club.

\section{Literature Review}

Previous research on the reasons for using impoliteness has not been done much. Similar research that has ever existed is a study conducted by Culpeper (1996) Towards an anatomy of impoliteness; in this study, Culpeper describes the factors behind the emergence of impoliteness. There are three factors behind impoliteness: the social relationship factor between the speaker and the speech partner, the difference in social level between the speakers, and the speaker's desire to deliberately not want to keep the face of the speech partner. Furthermore, Idrees (2020) research, A Socio-Pragmatic Analysis of the Impact of Impoliteness and Aggressive Language in Violent Online Games on The Players, discusses the use of impoliteness by players in the online game platform PUBG. In this study, impoliteness is used to express frustration, anger, and disgust towards others. In addition, the reason for using impoliteness in this study is the absence of social ties, ridicule, and jokes.

\subsection{Talk Show ILC}

The Indonesia Lawyers Club, which was familiarly called ILC, is a popular talk show in Indonesia, the talk show hosted by Karni llyas has been awarded five times with nine nominations for the Panasonic Gobel Award in the news talk show category (Wikipedia). The ILC talk show was broadcast live by the Indonesian National TV station, TVOne. In its presentation, the ILC talk show discusses issues currently being widely discussed in Indonesia. The talk show, which has been broadcast since 2017, has presented hundreds of speakers from various fields, such as law, politics, religion, health, environment, etc.

The talk show program was chosen as the data source for two reasons. First, talk shows are television programs, where the language used is generally the currently developing language in society. Second, speech events that occur in talk shows are dialogical or two-way. Two-way conversations are more interesting to study because, in dialogic conversations, the responses of the speech partners are also presented. 
The forms of impoliteness that appear in the ILC talk show are utterances that naturally arise from the speakers because the ILC talk show is broadcast live by TVOne. In the ILC talk show, two sides usually attack each other's arguments. Impolite utterances also often were used to defend each other's arguments. Therefore, the ILC talk show becomes an interesting resource to examine the extent to which impoliteness can occur through the factors behind the emergence of impoliteness.

\subsection{What is Impoliteness?}

Some argue that Culpeper's (1996) politeness theory is the opposite of Brown and Levinson's (1987) politeness theory, but impoliteness is not a simple reflection of the comparison of politeness theory. The theory of politeness was first put forward by Lakoff (1973), then Leech (1981), until later Brown and Levinson's (1978) theory emerged, which grouped politeness into five strategies. Bousfield and Locher (2008 :3) define impoliteness as "behaviour that is face-aggravation in a particular context. Impoliteness related to face notion is also stated in Brown and Levinson's (1987) theory that there is a negative face and a positive face. The face is interpreted as a person's self-image in general. Faces are categorized into two, namely positive face and negative face. A positive face is related to a person's desire to be accepted, treated equally by others, and appreciated for what he believes; on the contrary, a negative face is a need for an individual to be independent, have freedom of activity, without being restrained, and without coercion from anywhere. Lakoff (1989: 103) defines the language of impoliteness as "rude behaviour does not use politeness strategies where they would be expected, in such a way that the utterance can only almost plausibly be interpreted as intentionally and negatively confrontational". Furthermore, Beebe (1995:159) defines impoliteness as violence, "rudeness is defined as a face-threatening act (FTA) - or feature of an FTA such as intonation - which violates a socially sanctioned norm of the interaction of the social context in which it occurs".

Terkourafi (2008:70) explains the occurrence of impoliteness, "Impoliteness occurs when the expression used is not conventionalized relative to the context of occurrence; it threatens the addressee's face . . . but no face-threatening intention is attributed to the speaker by the hearer". Kienpointner (1997: 259) also assesses impoliteness as violence, "rudeness is a kind of prototypically noncooperative or competitive communicative behaviour which destabilizes the personal relationships of the interacting individuals".

Furthermore, Culpeper (1996) defines impoliteness as communicative strategies designed to attack face and thereby cause social conflict and disharmony. Impoliteness is a strategy deliberately expressed by the speaker to the speech partner to attack the speech partner's face. According to Culpeper (2005a: 38), "impoliteness comes about when: (1) the speaker communicates faceattack intentionally, or (2) the hearer perceives and/or constructs behaviour as intentionally face-attacking or a combination of (1) and (2)". Culpeper developed the theory of impoliteness into 5 main strategies, namely:

1. Bald on record Impoliteness

Bald on-record impoliteness or called direct impoliteness is an impoliteness strategy that is expressed or spoken by the speaker to the speech partner directly, clearly, and concisely in a situation where the speaker has no intention of keeping the face of the speech partner or does not want to maintain good relations with the speech partner.

2. Positive Impoliteness

Positive impoliteness or positive impoliteness is a strategy used by speakers to damage the positive face of the interlocutor. A positive face is a person's desire to be accepted, respected, wanted, needed, treated equally by others, and appreciated for what he believes. Positive impoliteness has several sub-strategies, including ignoring other people, ostracizing, withdrawing or separating from the speech partner, showing or expressing dislike, disinterest, and indifference, using names or nicknames that are not liked by the speech partner, making other people feel uncomfortable with the speaker's language, using taboo words, swearing, or abusive language.

3. Negative Impoliteness

Negative impoliteness aims to threaten the negative face of the speech partner. A negative face is the desire of an individual to be independent, have freedom of activity, without being restrained, and without coercion from anywhere. Examples of disruptive actions are scaring the interlocutor, ridiculing, criticizing, mocking, violating personal space, explicitly linking the interlocutor with negative things, making others seem indebted to the speaker, insulting others and arbitrarily treating them as well as belittling or demeaning others.

4. Mock politeness/ sarcasm

Mock impoliteness is a pseudo impoliteness strategy. Pseudo impoliteness is expressed with politeness so that it seems as if what is spoken is polite, even though it means the opposite. Politeness expressed has another purpose, such as making fun and so on. 
5. Withhold politeness

Withhold politeness is impoliteness that occurs due to negligence or the speaker's intentional not using the politeness that should be needed; for example, when they are helped, they do not say thank you or borrow other people's things; they do not ask permission first. Do not want to answer greetings and so on.

Furthermore, in Culpeper (1996), it is also stated that the theory of impoliteness is motivated by various factors, including:

1. Factors of social relations between speakers and speech partners Impoliteness can occur when the social relationship between the speaker and the listener is very close or intimate-the more familiar, the greater the possibility of impoliteness.

2. The second factor is the difference in social level between speakers. Speakers with higher social power will tend to be rude to speech partners with lower social power.

3. The speaker's intention of not wanting to keep the interlocutor's face. This situation may be motivated by conflicts or certain interests between speakers.

Based on some of the definitions of impoliteness above, it can be concluded that language of impoliteness is verbal behaviour that is directly or indirectly intended to damage or disturb someone's face.

\section{Methodology}

The Indonesia Lawyers Club, which was familiarly called ILC, is a popular talk show in Indonesia, the talk show hosted by Karni llyas has been awarded five times with nine nominations for the Panasonic Gobel Award in the news talk show category (Wikipedia). The ILC talk show was broadcast live by the Indonesian National TV station, TVOne. In its presentation, the ILC talk show discusses issues currently being widely discussed in Indonesia. The talk show, which has been broadcast since 2017, has presented hundreds of speakers from various fields, such as law, politics, religion, health, environment, etc.

The talk show program was chosen as the data source for two reasons. First, talk shows are television programs, where the language used is generally the currently developing language in society. Second, speech events that occur in talk shows are dialogical or two-way. Two-way conversations are more interesting to study because, in dialogic conversations, the responses of the speech partners are also presented.

The forms of impoliteness that appear in the ILC talk show are utterances that naturally arise from the speakers because the ILC talk show is broadcasted live by TVOne. In the ILC talk show, there are usually two sides that attack each other's arguments. Impolite utterances also often were used to defend each other's arguments. Therefore, the ILC talk show becomes an interesting resource to examine the extent to which impoliteness can occur through the factors behind the emergence of impoliteness.

\section{Results and Discussion}

In 3 episodes of the ILC talk show, 338 data on impoliteness were obtained. The three episodes are entitled Reklamasi Ancol? Anies Ingkar Janji, Pilkada Kenapa Takut, dan Setahun Jokowi- Ma'ruf Amin. 338 impoliteness data are classified based on the following characteristics and strategies:

1. Bald On Record Impoliteness

Bald on record impoliteness, also known as direct impoliteness, is an impolite utterance strategy deliberately carried out by the speaker to the speech partner to damage the face of the speech partner in a direct, clear, concise, and no-nonsense way. This strategy is generally spoken by speakers to the interlocutor to damage the interlocutor's face in front of other speakers and the audience of ILC events in the studio and at home. Based on data sources from three videos showing the Indonesia Lawyer Club, it was found that there were 75 forms of direct impoliteness strategies.

The following is an example of a direct politeness strategy found in an ILC event.

Context: The interaction occurred in the ILC event between Karni as the host and Asfina, who was the representative of YLBHI. In this speech event, Asfina answered a question from Karni regarding her response to Supratman's statement. Asfina gave a straightforward and firm response, stating that there were many problems in forming the Omnibuslaw Cipta Kerja.

Karni: Pemisa kita lanjutkan diskusi kita. Sekarang saya ke Asfinawati, Direktur YLBHI, bagaimana tanggapan anda terhadap keterangan Pak Supratman Andi Atgas tadi?

(Let's continue our discussion. Now I go to Asfinawati, Director of YLBHI; how do you respond to Mr Supratman Andi Atgas' statement earlier?) 
Asfina: Yak terima kasih em Bang Karni, selamat malam Bapak-bapak em dan lbu sekalian. Jadi sebetulnya ada banyak sekali masalah di dalam pembentukan Omnibuslaw Cipta Kerja itu.

(Yes, thank you, Bang Karni, good evening, ladies and gentlemen. So actually, there are many problems in the formation of the Job Creation Omnibuslaw.)

The speech event above involved Karni as the host and Asfina as a resource person for representatives of YLBHI (Indonesian Legal Aid Foundation). Karni asked Asfina about Asfina's response to Supratman's statement in this speech event. In the previous conversation, Supratman supported the existence of the Omnibuslaw, while Asfina rejected the Omnibuslaw. Based on this difference of opinion, Asfina answered Karni's question firmly, clearly, and directly with the statement, "So actually there are many problems in the formation of the Job Creation Omnibuslaw". The phrase 'a lot of problems' in Asfina's speech directly and intentionally damages the speech partner's face, in this case, the so-called speech partner, namely the resource person who supports the existence of the Omnibuslaw Cipta Kerja.

2. Positive Impoliteness

Positive impoliteness, also called Positive impoliteness, is a politeness strategy used by speakers to damage the positive face of the speech partner. A positive face can be interpreted as a person's desire to be accepted, respected, wanted, needed, treated properly, and appreciated for what he believes.

Context: The interaction occurred in the ILC event, which involved Syarief as a member of the DKI Jakarta DPRD from the Gerindra faction. In the conversation, Syarief did not agree with the use of the title of the ILC discussion that night which said that 'Anis Ingkar Janji' 'Anis broke his promise'.

Syarif: Kalau ada orang mengatakan Anies ingkar janji itu terlalu quotes banget ngangkatnya. Saya bisa mengatakan berat untuk mengatakan Pak Anies ingkar janji, apabila ada pihak yang mengatakan ingkar janji, orang kuat. Itu orang kuat, dan dibelakangnya pasti ada orang kuat.

(If someone says Anies broke his promise, it's too much of a quote to bring it up. I can say it's hard to say that $\mathrm{Mr}$ Anies broke his promise if there are parties who say he broke his promise, the strong person. It's a strong man, and behind him, there must be a strong person.)

In the above speech event in the episode 'Ancol Reclamation, Anies breaks his promise' Reklamasi Ancol, Anies ingkar janji', Syarief, who is a representative of the DKI Jakarta DPRD member from the Gerindra Faction, stated that he did not agree with the use of the phrase 'Anies Breaks his promise' which was used as the title of the ILC discussion. This was expressed by Syarief with the speech, "If someone says Anies broke his promise, it is too much of a quote.. ". In this speech, Syarief has indirectly attacked the interlocutor's face using positive politeness, namely by seeking disagreement.

3. Negative impoliteness

Negative impoliteness aims to threaten the negative face of the speech partner. A negative face is a person's desire to be independent, to have freedom of activity or opinion without being restrained and without coercion from others.

Context: The interaction takes place in the talk show ILC episode Pilkada, kenapa takut?' 'Pilkada, why are you afraid?'. This speech event involved dr. Ari is a resource person who represents health workers to convey the current condition of the Covid-19 pandemic if the Pilkada is still being held.

dr. Ari: Bapak-bapak bisa jalan-jalan sekarang ke IGD di rumah sakit rumah sakit rujukan atau kita lihat bagaimana kondisi ICU, apakah mudah sekarang mencari ICU untuk pasien covid, susah Pak, susah sekali saat ini.

(Ladies and gentlemen, you can go for a walk now to the ER at the referral hospital, or we will see how the condition of the ICU is, is it easy now to find an ICU for Covid patients? It's difficult, sir, very difficult right now.)

The speech event mentioned above in the episode Pilkada, kenapa takut? 'Pilkada, why are you afraid?' involves dr. Ari is a resource person. dr Ari is a representative of health workers to convey the condition of Covid-19 in Indonesia. In this debate, health workers refused to hold the Pilkada 'election' because the Covid-19 pandemic condition in Indonesia was still experiencing additional cases, while the camp that sided with the government supported the holding of the Pilkada in December. In his presentation, dr. Ari said, "is it easy now to find an ICU for Covid patients? It's difficult, sir, very difficult at this time", the speech was intended for speech partners who support the implementation of the elections. Based on speech (9), dr. Ari threatens the negative face of the interlocutor by scaring the hearer.

4. Mock Politeness 
Mock politeness or sarcasm is an impoliteness strategy that is expressed with politeness so that as if the words being spoken are polite when they mean the opposite. Politeness expressed actually has another purpose, such as making fun and so on. The following is an example of pseudo impoliteness used in the research data.

Context: The interaction takes place in the ILC talk show episode 'Pilkada, Kenapa Takut?'. 'Pilkada, Why Are You Afraid?'. This speech event involved Busyro, who is the chairman of PP Muhammadiyah. In his statement, Busyro expressed satire for the government.

Busyro: Jadi pada prinsipnya seperti itu yang bisa saya sampaikan, apa yang menjadi konsen dari pimpinan pusat Muhammadiyah yang jiwanya bersamaan dengan konsen dari ormas em NU bahkan juga hari ini ada pernyataan dari temen-temen organisasi keagamaan yang lain, mosok sih pemerintah tidak mendengarkan itu, saya kira Pak Jokowi masih punya nurani, masih punya intuisi sehingga kita doakan mudah-mudahan beliau bisa mengambil keputusan untuk ditunda dan kapan pengundurannya itu persoalan yang kemudian bisa dipecahkan bersama, begitu Bang Karni.

(So, in principle, that's what I can say, what is the concern of the Muhammadiyah central leadership whose soul is the same as the concern of the NU mass organization. Even today, there are statements from friends of other religious organizations, the government still doesn't listen to that, I think Mr Jokowi still has a conscience, he still has intuition, so we pray that he will be able to decide to postpone it and when his resignation is a problem that can then be solved together, said Bang Karni.)

The aforementioned speech event occurred in the ILC talk show episode 'Pilkada, Kenapa Takut?'. 'Pilkada, Why Are You Afraid?'. The speech incident involved Busyro, who is the chairman of PP Muhammadiyah. In his statement, Busyro expressed a form of apparent impoliteness by saying, " the government still doesn't listen to that, I think Mr. Jokowi still has a conscience ". Even though the speech looks polite, it actually contains impolite meaning because what you want to express is actually a satire or the opposite of politeness.

Furthermore, this study will discuss the reasons for using impoliteness in speech. In Culpeper's research (1996), the factors behind the emergence of impoliteness are grouped into 3; namely, the social relationship factor between the speaker and the speech partner, impoliteness can occur if the social relationship of the speaker and listener is very close or intimate, the second factor is the difference in social level between speakers. Speakers with higher social power will tend to disrespect the interlocutor with lower social power. The third is the desire of speakers who deliberately do not want to keep the interlocutor's face. This situation may be motivated by conflicts or certain interests between speakers. In the data source, namely the ILC talk show, the first and second factors are both owned by the speaker and the speech partner. Speakers and speech partners tend to have close social relationships, and speakers and speech partners also have the same level of education, so the third factor is chosen, namely the speaker's desire who deliberately does not want to keep the face of the speech partner. From the third factor, the researcher regroups the background of the use of impoliteness through the reasons why the speaker deliberately does not want to keep the interlocutor's face. Based on the data sources, it was found that there are 3 reasons why the speaker intentionally does not want to keep the face of the interlocutor, namely because the speaker feels that their opinion is the most correct, then because of the speaker's personal interests, and third, because the speaker wants to embarrass the speech partner.

\subsection{Feeling that their Opinion is Most Correct}

The first reason speakers use impoliteness to attack the partner's face is that the speaker feels that their opinion is the most appropriate and correct. The impolite expression that occurs because the speaker feels he is the most correct is found in one of the negative impoliteness strategies, namely the sub-strategy of blaming the speech partner. In addition to the negative impoliteness, the strategy was also found in the positive impoliteness strategy, namely the sub-strategy of seeking disagreement. The following is an example of the reasons for using impoliteness which is motivated by the speaker's attitude who feels the most correct.

Context: The speech event occurred in the ILC talk show episode Setahun Jokowi-Ma'ruf Amin, dari Pandemi sampai Demonstrasi One year Jokowi-Ma'ruf Amin, from Pandemic to Demonstration. This speech event involved Zaenal Arifin, who is an expert in constitutional law. In this speech event, Zaenal uses a strategy of impoliteness by blaming the speech partner because he feels that his opinion is the right one.

Zaenal: Waallahualam saya bukan meragukan kapasitas tapi bisa jadi akan dibangun kayak Bandung Bondowoso tu, ya, dikejar tu, bahwa dikatakan nanti diperbaiki oleh PP, saya tidak habis pikir bagaimana PP memperbaiki konsep UU, itu menyalahi pelajaran hukum yang saya pahami.

(Waallahualam does not doubt the capacity, but it may be built like Bondowoso, yes, it is chased, that is said to be later corrected by the PP, I could not understand how the PP improve the concept of the Act, it violates the law subjects that I understand.) 
The events mentioned above occurred in the ILC talk show episode of Setahun Jokowi-Ma'ruf Amin, dari Pandemi sampai Demonstrasi One Year Jokowi-Ma'ruf Amin, from Pandemic to Demonstration. The speech event involved Zaenal Arifin, who is an expert in constitutional law. On the occasion of speaking, Zaenal used impoliteness in one of his sentences by saying, "I can't understand how PP improves the concept of the Law; it violates the legal lessons I understand." Zaenal's expression has attacked the speech partner's face with a negative impoliteness strategy, with a sub-strategy of blaming the speech partner. Zaenal's utterances through the sentence 'can't understand how' contain implicatures that what the speech partner has done is wrong. Furthermore, the sentence 'violating the legal lessons I understand' implies that what the speaker understands is the most appropriate. Through the example data (27), it can be seen that the speaker uses a politeness strategy to blame the speech partner because what the speaker knows is the most appropriate. The form of the use of impoliteness which is motivated by the speaker's attitude, who always feels the most correct in the data source of the ILC talk show, found as many as 204 data.

\subsection{Speaker's Personal Interest}

The speaker's personal interest is the second background of using impoliteness in the ILC talk show. The speaker's personal interest here is the desire or implied message that the speaker wants to convey through the form of impolite speech. In the ILC talk show, the speaker's personal interest is one of the widely used reasons because every theme raised in the ILC episode is related to political and government issues. In this regard, the speakers presented are also people related in the field, and as it is known, what is conveyed in political issues is not related to the interests of the people in it. Therefore, the speaker's personal interest is one of the reasons for using impoliteness in the ILC talk show. The following is an example of the use of impoliteness which is motivated by the speaker's personal interests.

Context: The speech event occurred in the ILC episode of Reklamasi ancol, Anies Ingkar Janji? Ancol reclamation, Anies broke Promise? The speech event involved Syarief as a member of the DKI Jakarta DPRD from the Gerindra faction. In the conversation, Syarief did not agree with the use of the title of the ILC discussion that night which said that 'Anis broke his promise'.

Syarif: Kalau ada orang mengatakan Anies ingkar janji itu terlalu quotes banget ngangkatnya. Saya bisa mengatakan berat untuk mengatakan Pak Anies ingkar janji, apabila ada pihak yang mengatakan ingkar janji, orang kuat. Itu orang kuat, dan dibelakangnya pasti ada orang kuat.

I can say it's hard to say that Mr. Anies broke his promise if there are parties who say he broke his promise, the powerful person. (If someone says Anies broke his promise, it's too much of a quote to bring it up. It's a powerful man, and there must be a more powerful person.)

The speech event mentioned above occurred in the ILC talk show episode of Reklamasi ancol, Anies Ingkar Janji? Reklamsi Ancol, Anies Ingkar Janji? The speech event involved Syarief, who was a representative of the members of the DKI Jakarta DPRD from the Gerindra Faction. Syarief's data stated that Anies did not break a promise through utterance, "Anies breaking a promise is too much of a quote to bring it up. I can say that it's hard to say that Mr. Anies broke his promise," Syarief emphasized in the utterance that those who said Anies broke his promise were said to be 'too quotes', and this was considered incorrect by Syarief. The form of politeness spoken by Syarief is a positive politeness strategy motivated by the speaker's interests. In the context of this conversation, Syarief is a representative of a member of the DKI Jakarta DPRD, so he has an interest in supporting and defending Anies, who is the Governor of DKI Jakarta. Therefore, the expressions of impoliteness expressed by Syarief are motivated by the speaker's interests. The form of the use of impoliteness motivated by the speaker's interests is also found 56 times in the data source.

\subsection{Wanting to Embarrass the Speech Partner}

The third background of the use of impoliteness in the ILC talk show is the desire to embarrass the interlocutor. Impolite utterance motivated by the desire to embarrass the speech partner occurs when the speaker intentionally uses impoliteness to embarrass the speech partner in front of many people. Forms of impoliteness that can embarrass the speech partner include demeaning, ridiculing, mocking, using insulting nicknames, issuing harsh words, ignoring the speech partner. The following is an example of impoliteness motivated by the desire to embarrass the interlocutor in the ILC talk show.

Context: Speech events occur in the ILC episode of Setahun JokowiMa'ruf Amin, dari Pandemi hingga Demonstrasi. Jokowi Ma'ruf Amin's One Year episode, from Pandemic to Demonstration. The speech event involved Rizal Ramli, who is a senior economist. In this speech event, Rizal humiliated the speech partner by using impoliteness in the form of a derogatory nickname to refer to the speech partner.

Rizal: Nah poin saya adalah emm makanya saya sebut 'menteri keuangan terbalik', terbaik buat debitur, buat bank yang kasih pinjem, terbalik buat rakyat Indonesia.

(So my point is, that's why I call it 'minister of upside-down finance', upside down for debtors, for banks that lend, and upside down for the people of Indonesia.) 
The speech event mentioned above occurred in the ILC talk show episode of Setahun JokowiMa'ruf Amin, dari Pandemi hingga Demonstrasi. One Year Jokowi-Ma'ruf from Pandemic to Demonstration. In his utterance, Rizal expressed a form of impoliteness by calling the finance minister upside down. "That's why I call the minister of upside-down finance, upside down for debtors," Rizal's statement threatened the positive face of the interlocutor. Rizal's statement was motivated by the desire to humiliate the speech partner. The form of impoliteness, which is motivated by the desire to embarrass the speech partner, was found 79 times in the data sources.

Tables (1) Frequency of Reasons for Using Impoliteness in Indonesia Lawyers Club talk shows

\begin{tabular}{|l|l|l|l|}
\hline No. & $\begin{array}{l}\text { Background to the use of impoliteness in ILC talk } \\
\text { shows }\end{array}$ & Amount & Percentage \\
\hline 1 & Feeling the Most Right Opinion & 204 & $60.17 \%$ \\
\hline 2 & Speaker's Personal Interest & 56 & $16.51 \%$ \\
\hline 3 & Want to Embarrass Speech Partner & 79 & $23.30 \%$ \\
\hline & Amount & 339 & \\
\hline
\end{tabular}

From three sources of data on ILC's YouTube Talkshow, it was found that as many as 338 impolite sentences were expressed by speakers to their interlocutors. Of the 338 data, the background of the use of impoliteness by speakers in the ILC talk show is dominated by the reason that the speaker feels his opinion is the most correct, which is 204 data, the next reason is because of the speaker's personal interest as much as 56 data, and the last reason is the speaker's desire to humiliate the speech partner as much as 79 data.

Tables (2) Politeness Strategies and Reasons for Its Use in ILC talk shows

\begin{tabular}{|c|c|c|c|c|c|c|}
\hline No & Reasons to use impoliteness & $\begin{array}{l}\text { Bald On } \\
\text { Record } \\
\text { Impoliteness }\end{array}$ & $\begin{array}{l}\text { Positive } \\
\text { Impoliteness }\end{array}$ & $\begin{array}{l}\text { Negative } \\
\text { Impoliteness }\end{array}$ & $\begin{array}{l}\text { Mock } \\
\text { Politeness }\end{array}$ & Amount \\
\hline 1 & Feeling the Most Right Opinion & 42 & 27 & 109 & 27 & 204 \\
\hline 2 & Speaker's Personal Interest & 13 & 14 & 17 & 11 & 55 \\
\hline \multirow[t]{2}{*}{3} & Want to Embarrass Speech Partner & 21 & 10 & 17 & 31 & 79 \\
\hline & Amount & 75 & 51 & 143 & 69 & 338 \\
\hline
\end{tabular}

The table above shows the frequency of reasons for using impoliteness against impoliteness strategies. The use of impoliteness because the speaker feels that his opinion is the most correct is dominated by 109 utterances of negative impoliteness, then using 41 utterances of bald on record, 27 utterances of positive impoliteness, and 27 utterances of mock impoliteness. Speakers use more negative impoliteness to express impoliteness because they feel their opinion is correct.

The reason for the use of further impoliteness is because of the speaker's personal interests, mostly found in the negative impoliteness strategy as many as 17 utterances, then positive impoliteness with 14 utterances, bald on record impoliteness with 13 utterances, and mock impoliteness with 11 utterances. When compared, the number of uses of impoliteness due to the personal interests of the speaker is not much different. Furthermore, the reasons for wanting to embarrass the speech partner, the speaker's desire to humiliate the speech partner is dominated by the use of mock impoliteness, which is 31 utterances, bald on record impoliteness as many as 21 utterances, negative impoliteness as many as 17 utterances, and positive impoliteness as many as 10 utterances.

Based on the analysis of data sources, it can be concluded that Culpeper's (1996) theory can be applied to data sources, but the theory is not complete, especially on the factors behind the emergence of impoliteness. This study tries to complement the existing Culpeper theory. In Culpeper's theory, it is stated that there are 3 factors behind the emergence of impoliteness, namely the social distance between speakers, differences in the level of social status between speakers, and the desire of speakers who deliberately do not want to keep the face of the interlocutor. Based on data analysis, the first and second factors are owned by ILC talk show speakers. They are considered to have the same social distance and the same level of social status. This is because the people who are the speakers in the ILC talk shows are usually experts in certain fields of science or are spokespersons for representatives from the government. 
Furthermore, after being re-examined based on the data, the reason for the speaker's intentional use of impoliteness towards the speech partner is based on several other additional reasons. Based on the data sources, it was found that there are three reasons why speakers deliberately do not want to keep the face of the interlocutor, namely because they feel that their opinion is the most correct, then for the personal interest of the speaker, and deliberately wants to embarrass the face of the interlocutor. Therefore, the third factor, namely the desire of the speaker who deliberately does not want to keep the interlocutor's face, is the reason for using impoliteness in the ILC talk show.

Feeling that his opinion (the speaker) is the most correct is the most common reason found in the use of impoliteness. The speaker expresses impoliteness to the interlocutor when he feels that his opinion is correct. When someone believes that what he expresses/says is the truth and does not want his opinion to be refuted by others, he will tend to express it with disrespectful expressions. The next reason for using impoliteness is the speaker's personal interest. Every speaker has an interest that he wants to convey to the hearer and the audience. The speaker hopes that what he says can be accepted and gets support from the audience. Therefore, there is much impoliteness in ILC talk shows based on the speaker's personal interests. The next reason is wanting to embarrass the speech partner. Some speakers deliberately want to put down or embarrass the interlocutor in public to express disrespectful sentences in front of the interlocutor and the audience to embarrass the interlocutor.

\section{Conclusion}

The use of impoliteness in 3 episodes of the ILC talk show was found to be 339 data. Of the 339 data, the impolite utterance was dominated by negative impoliteness strategies as many as 143 data; then the direct impoliteness strategy found 75 data, pseudo impoliteness strategies as many as 69 data, and positive impoliteness strategies as many as 51 data.

The background of impoliteness in Culpeper (1996) is categorized into three main factors: the distance of social relations between speakers, differences in the level of social status between speakers, and the speaker's desire to deliberately not want to keep the face of the interlocutor. The factor of social distance and differences in the level of social status between speakers is not a factor that is the reason for speakers in the ILC talk show to use impolite utterances. This is because, in the ILC talk show, each resource person has close social distance and equal social status. Therefore, two of the three factors presented by Culpeper (1996) cannot represent the reasons for using impoliteness in the ILC talk show.

Furthermore, there is only one factor behind the use of impoliteness in the ILC talk show, namely the desire of the speaker who deliberately does not want to keep the interlocutor's face. Using one of these factors, a more in-depth data analysis was carried out on the background of the speakers in the ILC talk show who deliberately did not keep the interlocutor's face. Based on data from 3 episodes of the ILC talk show, three reasons were found to dominate the speaker's intentional refusal to guard the face of the interlocutor, namely because the speaker felt the most correct, the speaker's personal interest, and the speaker's desire to embarrass the speech partner. Based on these three reasons, the speaker's most dominant reason for not keeping the interlocutor's face is the speaker's attitude, who feels that his opinion is the most correct.

This reason arises because many impolite utterances in ILC talk shows tend to be followed by the speaker's personal opinion, which is something that the speaker believes to be true. As it is known, the ILC talk show presents competent sources in their fields so that they will express their respective opinions that they believe in. Thus it can be concluded that the speakers in the ILC talk shows tend to compete so that their opinions are heard by the public and can indirectly threaten the faces of their partners.

Funding: This research received no external funding

Conflicts of Interest: The authors declare no conflict of interest.

ORCID iD: Sukmawati Putri, Dita: https://orcid.org/0000-0002-8839-9495

\section{References}

[1] Archer D. E (2008). Verbal aggression and impoliteness: related or synonymous? in Derek Bousfield and Miriam A. Locher (Eds.), Impoliteness in Language: Studies on its Interplay with Power in Theory and Practice. Berlin: Mouton de Gruyter, 181-210. 
[2] Beebe, L. M (1995). Polite fictions: Instrumental rudeness as pragmatic competence. Georgetown University round table on languages and linguistics, 1995, 154J168.

[3] Bousfield, D and Miriam L. (eds.). (2008). Impoliteness in Language: Studies on its Interplay with Power in Theory and Practice. Berlin and New York: Mouton de Gruyter.

[4] Brown, P and Levinson, S. C. (1987). Politeness: Some Universal in Language Usage. Cambridge: Cambridge University Press.

[5] Culpeper J. (2005). Impoliteness and entertainment in the television quiz show: The Weakest Link. Journal of Politeness Research, Vol 1, p. 3572.

[6] Culpeper J. (1996). Towards an anatomy of impoliteness. Elsevier: Journal of Pragmatics., Vol. 25, p. 349-367.

[7] Goffman, E. (1967). On face-work, interaction ritual: Essays on face-to-face behaviour. New York: Pantheon.

[8] Idrees, FAG (2020). A Socio-Pragmatic Analysis of the Impact of Impoliteness and Aggressive Language in Violent Online Games on the Players. International Journal of Linguistics, Literature and Translation, 3(11), 206-216. https://doi.org/10.32996/ijllt.2020.3.11.20

[9] Kienpointner, M. (1997). Varieties of rudeness: Types and functions of impolite utterances. Functions of Language 4 (2): $251-87$.

[10] Lakoff, RT (1989). The limits of politeness: Therapeutic and courtroom discourse. Multilingual 8 (2-3): 101-29.

[11] Lakoff, RT (1973). The logic of politeness or minding your p's and q's. Papers from the Ninth Regional Meeting of the Chicago Linguistic Society: 292-305.

[12] Leech, GN (1981). Semantics: The Study of Meaning (2nd edn). Harmondsworth: Penguin Books.

[13] Limberg H. 2009. Impoliteness and threat responses. Journal of Pragmatics., Vol.41, p.1376-1394.

[14] Nugroho, M. (2013). Data and Data Acquisition Methods in Pragmatic Research. p. 504. in the Development of the Role of Indonesian Language and Literature to Create a Character Generation. International Seminar Proceedings. Eleven March University, Surakarta.

[15] Sudaryanto. (1993). Methods and Various Techniques of Language Analysis. Yogyakarta: Duta Wacana Press.

[16] Terkourafi, M. (2008) Towards a unified theory of politeness, impoliteness, and rudeness. In: Derek Bousfield and Miriam L (eds.) Impoliteness in Language: Studies on its Interplay with Power in Theory and Practice. Berlin and New York: Mouton de Gruyter, pp. 45-74.

[18] Wikipedia. (2008). Indonesian Lawyers Club. https://id.wikipedia.org/wiki/Indonesia_Lawyers Club. (14 April 2020, Semarang at 22.45 WIB). 